\title{
The TED Talks as a Learning Tool in Teaching Speaking
}

\author{
M. Sofian Hadi' ${ }^{\text {, Mutiarani }}{ }^{2}$, Mutiara Indah Sari ${ }^{3}$ \\ Universitas Muhammadiyah Jakarta, South Tangerang, Banten \\ ${ }^{1}$ mutiaraindah818@gmail.com
}

\begin{abstract}
This study aims to analyze the improvement of Speaking Skills by using the TED Talks Application. The writers carried out in class 12 OTKP of the SMK Muhammadiyah Parung. This researcher used the quantitative method, the quantitative method used quasi-experimental design using the one-group design by purposive sampling technique by selecting 20 students from class 12 OTKP and every student test for pre-test and post-test for data collection. The quasiexperimental design test whether there is a causal relationship between independent and dependent variables. The study lasted eight weeks and the writers compared the result of the pre-test and post-test use spss 25 ver. to conclude the result of the research. After analyzing the data using the Paired Sample t-test method, the pre-test and post-test t-test were 28,59 and the df t-value was 2,093. As the $t$-value was higher than the t-value of $\mathrm{df}(28,59>2,093)$, the writers concluded that the use of the TED Talks Application was effective in improving speaking skills.
\end{abstract}

Keywords:TED Talks Mobile Application, English Speaking, Learning Method

\section{INTRODUCTION}

Nowadays, the statements "Industrial Revolution 4.0" is heard all over the world. It has been reported that technology innovations have emerged rapidly in all aspects of life, particularly in Indonesia. Technology is very important in the field of education. It enables teachers and students to carry out the learning process. Technology has also been addressed in English language learning in higher education. Many teachers use devices, such as mobile device, as a tool to support and facilitate the teaching and learning environment. According to West and Vosloo (2013) in Howlett and Waemusa (2019), mobile devices give students the freedom to pursue their interest at their own pace, which can boost their motivation to pursue learning opportunities. Furthermore, the use of mobile devices in the language learning process is referred to as mobile assisted language learning (MALL). Since language is important for communication, it is not enough for students to learn words, phrases, and grammar if they want to produce language in their daily communication or communicate with others in English. Afshar and Asakereh suggest that a language is a key tool for communication. It involves the whole individual, community, education, creation of the communicative method, Afshar \&Asakereh (2016:112-130).

Smartphone by far, the most popular. A mobile application, also known as a mobile app, is software that is programmed to run on mobile devices like smartphones, laptop, and personal digital assistants (PDAs) (Liu \& He, 2014). English language learning reaches a new era with the aid of mobile apps. Boredom, which is also caused by 
tradition, can be reduced by using a smartphone application to assist with learning English. Furthermore, a large number of mobile applications for English speaking learning have been created. It is state that speaking is the most difficult skill for students, and that there are insufficient opportunities for speaking practice (Ahn\& Lee, 2016). Several studies have also found that EFL students have a difficult time learning English speaking. According to a study conducted by Coskun (2016), Turkish EFL students are unable to speak English fluently due to a variety of factors including a lack of international experience, insufficient speaking practice opportunities outside of the classroom, and feeling nervous when speaking a foreign language. Stated to a study by Al-sobhi\&Preece (2018) most Arab students struggle to communicate openly in English due to a variety of factors including student's poor knowledge of the English language, lack of trust, and motivation. Furthermore, according to Hamad, Metwally, and Alfaruque (2019), both teachers and learners struggle with body language, proper pronunciation of English letters, intonation, belief, and proper vocabulary use. Teachers must be able to teach four language skills 9reading, writing, listening, and speaking) simultaneously in just 80 minutes, making it nearly impossible to complete.

Other than, according to Hughes in Yolanda \&Hadi (2019:3) the goal of speaking is communicative. Speaking is an interactive process of building meaning that includes generating, receiving, and processing information. Later, Thornbury\& Scoot (2012) is a more nuanced practice that includes not only grammar and vocabulary but also several things such as skill management and other skills. The ability to speak does not only play an important role in learning but is also plays important role in other learning, Chien et al., (2019). When the learners engage in conversation, the object of speaking here may be to express views, to reassure others, or to clarify facts. As an effect, the advent of mobile apps for learning English on smartphones offers opportunities for students to increase their motivation to learn English. Furthermore, the mobile applications availability and versatility allow students to devote more time to speaking practice. They will be able to practice speaking English both in and out of the classroom. Moreover, according to Gonzalez (2012), using mobile apps to learn how to speak has a lot of potential for practicing and improving specific aspects of English pronunciation, including individual phonemes, tension, and intonation.

TED Talks is a downloadable app that can be used to help students learns to communicate from the hundreds of speaking apps available on the app store. The TED Talks app, which is available for free on smartphone, has a variety of exercise to help you practice speaking English. TED Talks were made available in the TED website, over 1800 talks and a wide variety of 35.000 transcript in many languages were made available to the public, Taibi Chawla \&Fetahu (2015:147). Indeed, initially it was only ideas about Technology, Entertainment, and Design, but now it has started to develop with figures with other backgrounds such as health, education, politics, and others. These apps features are intended to help you improve your pronunciation, intonation, accents, phrases in relevant contexts, and vocabulary. One of the features in the TED Talks app is the ability to interact with people who are learning English using the public speaking method from all over the world so that they can practice English together, beginning with how to communicate, express thoughts, presents presentations, and so on, so that the audience can see how they are drawn into the discussion that is being discussed. It's unusual for them to use comedy to make the viewer feel more at ease. 
This research, on the other hand, is thought to be unique in comparison to some previous related studies. According to Nguyen and Boers (2019) in general, English students are asked to watch a TED Talk video to outline material orally in English, and then watch the video again. Then Guo (2015) conducted a previous study that looked at the relevant learning theories that underpin the existing mobile apps for English language learning. Besides, the previous study by Han and Keskin (2016) look at the use of a mobile app to help people with EFL speaking anxiety.

For this reason, the writers needed to limit the study. This is meant to stop big problems and help them concentrate on research. In connection with the problem context and problem recognition, this study will focus on improving student's English proficiency by using the TED Talks application. The reason why the writers chose it is because the TED Talks application can make it easy for students to generate new ideas, think creatively, and stay motivated all the time and can eliminate boredom and inspire students. Therefore, the writers assume that this would give them more opportunities to practice speaking in class. From a point of view, this research was conducted with a focused on improving the speaking skills of grade 12 students of SMK Muhammadiyah Parung by using the TED Talks application. Based on the limitation of the problem above, the formulation in this study: Does the TED Talks Application can used to improve students speaking skills in English?

\section{METHOD}

The writers used the design quantitative research would a quasi-experimental design, which used one group pre-test and post-test design. Quasi-experimental design examines whether there is a causal relationship between independent ( $\mathrm{X}$ Variable) was TED Talks Application and dependent variable (Y Variable) was Speaking Skill. Besides, Fraenkel \& Wallen (2011:265) in a one-group pre-test design, one group is assessed or examined before and after exposure to treatment. Thus, the writers only compared the score of students speaking skills before treatment with TED Talks app and the score of students speaking skills after treatment wits TED Talks.

Then, the writers choose the participants of the study were 20-grade 12th OTKP students at SMK Muhammadiyah Parung. For a lot of conditions, they were selected using objective sampling. First, students are often assigned to watch videos in English to improve their speaking skills. Second, participants are excited to learn from technological innovation. Third, SMK Muhammadiyah Parung is a trusted member of technology-assisted learning and has applied it both inside and outside the classroom. As a result, students have a variety of ways to use technology to promote independent learning.

As the writers needed to gather the data, the method of collecting the data was pre-test and post-test. The writer does pre-test and post-test to know about students' progress in speaking skills and know whether TED Talks application can enhance students' ability speaking skill or no. after collecting the data, the writers need to analyze the writers uses the help of the SPSS computer program. SPSS is a program for processing statistical data which is quite easy to use. To be able to use SPSS, the writers should have mastered the basics of statistics so that it would be easier to understand how to analyze data and read the results. The writers also evaluated using a t-test. To assess if there is a substantial difference between the means of the study before and after treatments. After getting the $t$ value ( $t$ obtained), is then compared with the $t$ 
critical if $t$ obtained $\geq t$ critical at the level of significance $(\mathrm{p})=0.05$, the null hypothesis (Ho) is rejected and accepts the alternative hypothesis (H1). However, if $t$ obtained $\leq \mathrm{t}$ critical then the null hypothesis is accepted.

\section{RESULTS AND DISCUSSION}

The writers would research one group or one class, the structure with analysis in class was as follows:

Table 1. Structure of Research of One Class

\begin{tabular}{|c|c|c|c|c|}
\hline $\begin{array}{c}\text { Students } \\
\text { of } 12 \\
\text { OTKP }\end{array}$ & $\begin{array}{c}\text { Give the } \\
\text { Pre-test }\end{array}$ & $\begin{array}{c}\text { Give the } \\
\text { treatments }\end{array}$ & $\begin{array}{c}\text { The Last } \\
\text { Give the } \\
\text { Post-test }\end{array}$ & $\begin{array}{c}\text { The } \\
\text { result of } \\
\text { the } \\
\text { research }\end{array}$ \\
\hline
\end{tabular}

Based on this table, the writers discuss pre-test the students first give the treatment to students. After doing the pre-test, the writers would give treatment to students. Every student would get the same treatment, right away this study uses a Quasi-Experimental Design. The treatment would take several times. Then the writers would begin to analyze the results of the pre-test and post-test afterward complete the research. Before analyzing data through SPSS, writers compared percentages result in class.

During the research period as writers after examining the pre-test, the writers were also able to see the difference between the post-test. Students in class can practice speaking better than before. Thus, students can become taller scores in putting it into practice. The writers discussed the pre-test result with students. In the discussion, students still did not understand the test questions they still have some questions they don't understand.

In class, students explain that they don't understand if they had to speak English all the time and can't understand everything they say. They too added that they only understand a little vocabulary when they are told to speak English. Because they still feel less confident and lack expression when they speak in English.

In further explanation, students also explain the English teacher doesn't teach speaking material with practice methods the teacher also did not provide further explanations about the teaching materials and only gave homework or test as a tool to help students. In short, teachers don't provide more practice in speaking English or motivation about speaking material in class.

Then the writers conducted research to improve speaking skills in OTKP class 12 . Shortly after conducting the pre-test, the writer began teaching in class using the TED Talks Application to motivate students to be confident when speaking English. The writer takes 45 minutes for teaching materials in class and 15 minutes for discussion. The writers prioritized learning speaking skills at lesson time because most students need to practice them to increase their self-confidence to improve speaking skills. The activity lasted for a few weeks. 
After several weeks of teaching, the writers analyzed these improvements students in the class. As writers provide training sheets every week, students are more interested in practicing it in front of the class and can increase their confidence when speaking English by using the TED Talks Application as a media and material that is more fun than traditional techniques. The calculation is:

\begin{tabular}{lll|lll} 
& Mean & $\mathrm{N}$ & $\begin{array}{l}\text { Std. } \\
\text { Deviation }\end{array}$ & $\begin{array}{l}\text { Std. } \\
\text { Mean }\end{array}$ \\
\hline Pair 1 & PRE-TEST & 64.7000 & 20 & 3.96166 & .88585 \\
\cline { 2 - 6 } & POST-TEST & 87.6000 & 20 & 5.21536 & 1.16619 \\
\hline
\end{tabular}

Table 2. Mean Results Pre-test and Post-test

Table 2 shows that explain the difference between the two scores through pre-test mean. The pre-test mean was 64.70 whereas the mean post-test class was 87.60. Then, even though the students got better results than the pre-test. as a writer using conventional or traditional techniques. In teaching material because the writer uses the TED Talks application in teaching. Furthermore, the writer calculated the data through the Paired-Samples T-test in SPSS. The statistical results are:

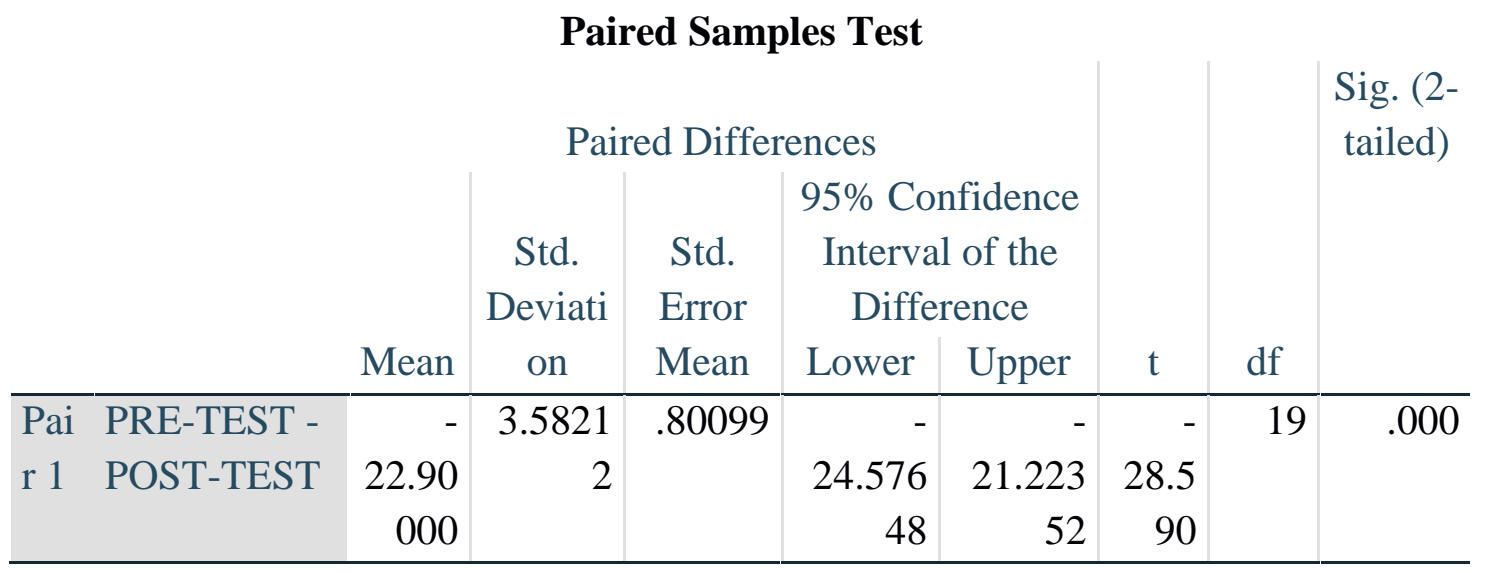

Table 3. Paired Samples T-test

Based on the table 3, the t value is -28.590 and the value also becomes positive because of the statistical formula. Then 0.05 / 2 and the value become 0.025 . Df was 19 so value $\mathrm{df}$ was 2,093 . As the $t$ value of pair 2 is higher than the $t$-value of $\mathrm{df}(28.59>2.093)$ the researcher concluded that using the TED Talks application for students in the classroom was very effective for improve speaking English.

Then, based on these calculations and statistics, the writers found research has had a positive impact on improving speaking skills. Furthermore, this research indicated that through TED Talks video, the students get knowledge about speaking and they can motivate because the speakers tend to tell about their life experience, so that the 
students get new ideas and further information. Endahati (2016:18) states that audio visual aids become one of the media used in language teaching and learning especially in speaking subject, this kind of medium will motivate students to speak and deliver their ideas easily. Teachers may use this media/application for teaching materials in English lessons. Because the results of the research are clear, the writers were giving the final project the conclusion is that the application for TED Talks will be very effective in teaching English.The study quantitative findings indicate that there is a substantial difference between students mean pre-test and post-test scores, with a Sig. (p-value) of 0.000 being less than 0.05 . based on the mean score of the pre-test and post-test, it can be concluded that students speaking capacity has improved.

The writers drew some conclusions from their results. First, the writers discovered this based on the study statements from the pre-test results. Students are perplexed on how to give a speak in front of class so that the students can understand the speaker clearly by using TED Talks application in speaking classes. In reality, different types of issues were discovered because of the study. Overall, they had a good time teaching speaking using the TED Talks application. Furthermore, students believe that using TED Talks app has given them a new way to learn speaking English. Other, the indicate that students are enthusiastic about learning in the classroom, and that teachers encourage and empower them to do so, as well as providing encouragement for the improvement of their speaking skill. And second the writers give the students post-test, the findings show that watching TED Talks app will help to improve speaking skills. The way the writers thought them was well received by the students. Furthermore, the finding show that the writers use a variety of learning strategies to accomplish objective instruction, and that the writers seeks to find a solution focused on the needs of the students in a variety of ways.

\section{CONCLUSION}

Based on the above results and discussions, it can be concluded that there is a significant increase in students' performance following the use of the TED Talks application for learning English, in particular speaking skills. This shows that the Sig. (pvalue) is $0.000<0.05$, which means that there is a significant difference between the mean pre-test and post-test. It is therefore suggested that the TED Talks application may be an alternative tool to support the teaching and learning process in English, this study is limited to a narrow area, and it is suggested that further research may reveal more broadly the discovery of the impact of the TED Talks application on students themselves.

Then, writers recommend teacher to involve needs to be developed to improve students speaking skill use of TED Talks App. TED Talks App is very useful because it provides all the aspects of speaking skill. The students can see flow of the speech and observe the speaker's techniques in delivering te speech, so that they can learn from the speakers. Based on the result, most of the students have positive beliefs about the use of TED Talks App to improve students speaking skill. This research is expected to motivate and inspired the future researcgers to conduct the same research about the use of TED Talks App. They can apply it in listening, reading class, etc. Lastly, the writers hope this article and the result can help other researcher as sources of their research that involved audio visual in learning material technique.

50 | ENGLISH EDUCATION

Journal of English Teaching and Research 


\section{REFERENCES}

Afshar, H. S. (2016). Speaking skill problem encountered by iranian EFL freshmaen and seniors from their own and their englishinstructors perspective. electronic journal of foreign language teaching, 112-130.

Ahn, T., \& Lee, S. (2016). User experience of a mobile speaking application with automatic speech recognition for EFL learning. British Journal of Educational Technology, 47(4), 778-786. https://doi.org/10.1111/bjet.12354

Al-sobhi, B. M. S., \&Preece, A. S. (2018). Teaching English Speaking Skills to the Arab Students in the Saudi School in Kuala Lumpur: Problems and Solutions. International Journal of Education \& Literacy Studies, 6(1),

Boers, c.-d. n. (2019). The effect of content retelling on vocabulary uptake from a TED talk. TESOL International Assosiation, 5-25.

Chien. S. Y. (2019). Effects of Peer Asessment Within the Context of Spherical VidioBased Virtual Reality on EFL students English Speaking Performance and learning Perception. Computer \& Education, DOI:https://doi.org/10.1016/j.compedu.2019.10375.

Coskun, A. (2016). Causes of the "I Can Understand English, but I Can't Speak' Syndrome in Turkey. I-Manager's Journal on English Language Teaching, 6(3), 1-121-11. http://dx.doi.org/10.7575/aiac.ijels.v.6n.1p.1

Creswell, J. W. (2013). Research Design: Qualitative, Quantitative, and Mixed Methods Approaches. Thousand Oaks, California: Sage Publications.

Endahati, N. (2016). Analysis of the effectiveness of public speaking subject module information-technology (it) based. Retrieved on May 4, 2021, from journl.uad.ac.id/index.php/ADJES/article/view/3622.

Fraenkel, J. R. (2011). How to Design and Evaluate Research in Education. New York: McGraw-Hill.

Guo, H. (2015). Analysing and Evaluating Current Mobile Applications for Learning English Speaking Author Name: Hui Guo. Birkbeck, University of London.

González, J. F. (2012). Can Apple’s iPhone Help to Improve English Pronunciation Autonomously? State of the App. CALL: Using, Learning, Knowing. EUROCALL Confrence, 81-87. Gothenburg, Sweden: Dublin 2012.

Hamad, M. M., Metwally, A. A., \&Alfaruque, S. Y. (2019). The Impact of Using YouTubes and Audio Tracks Imitation YATI on Improving Speaking Skills of EFL Learners. English Language Teaching, 12(6), 191-198. https://doi.org/10.5539/elt.v12n6p191

Han, T., \&Keskin, F. (2016). Using a Mobile Application (WhatsApp) to Reduce EFL Speaking Anxiety. Gist Education and Learning Research Journal, 12, 29-50.

Howlett, G., \&Waemusa, Z. (2019). 21st Century Learning Skills and Autonomy: Students' Perceptions of Mobile Devices in the Thai EFL Context. Teaching English with Technology, 19(1), 72-85

Liu, Q., \& He, X. (2014). Using Mobile Apps to Facilitate English Learning for Collage Students in China. University of Boras.Machmud, K., \&Abdulah, R. (2018). Using Mobile Phone to Overcome Students' Anxiety in Speaking English. SHS Web of Confrences, 42,1-6. https://doi.org/10.1051/shsconf/20184200004

Nguyen, C. D., \& Frank. B. (2019). The Effect of Content Retelling on Vocabulary Uptake from a TED Talk. TESOL International Assosiation, 5-25.

Sari, P. (2017). Using Vlog in the Youtube Channel as a Means to Improve Students'Motivation and Confidence to Speak English in Intermediate 1 Level of 
LB-LIA Jambi. International Journal of Language Teaching and Education, 1(1), 38-44.DOI: https://doi.org/10.22437/ijolte.v1i1.4596.

Taibi, D. C. (2015). Exploring TED Talks as Linked Data for Education. British Journal of Education Technology . doi:10.1111/bjet.12283

Thornbury, S. \&. (2015). How To Teach Speaking-Scoot Thronbury. Journal of Education and Practice. (Vol 3). https://doi.org/10.1093/eljt/cci025.

Yolanda, D., \&Hadi, M. S. (2019). Using Puppet Games in Teaching Speaking for Tenth Graders of Senior High School. English Language in Focus (ELIF), 1-8.

https://people.howstuffworks.com/ted-talks1.htm. Roos. (n.d.). How tED Talks work. (Retrieved December 2nd 2019)

https://people.howstuffworks.com/ted-talks1.htm. (Retrieved December 2nd 2019 